\title{
The 2030 Agenda for Sustainable Development in Nigeria: The Role of the Architect
}

\author{
Nnaemeka-Okeke Rosemary Chidimma, Okeke Francis Ogochukwu*, Sam-Amobi Chinwe \\ Department of Architecture, University of Nigeria, Enugu Campus, Enugu, Enugu State, Nigeria \\ Email address: \\ rosemary.nnaemeka-okeke@unn.edu.ng (Nnaemeka-Okeke R. C.), ogochukwu.okeke@unn.edu.ng (Okeke F. O.), \\ chinwe.sam_amobi@unn.edu.ng (Sam-Amobi C.) \\ ${ }^{*}$ Corresponding author
}

\section{To cite this article:}

Nnaemeka-Okeke Rosemary Chidimma, Okeke Francis Ogochukwu, Sam-Amobi Chinwe. The 2030 Agenda for Sustainable Development in Nigeria: The Role of the Architect. Science, Technology \& Public Policy. Vol. 4, No. 1, 2020, pp. 15-21. doi: 10.11648/j.stpp.20200401.13

Received: April 3, 2020; Accepted: April 26, 2020; Published: May 15, 2020

\begin{abstract}
The 2030 agenda for sustainable development seeks to eradicate poverty which is considered as a global challenge and also, a requirement to achieve sustainable development for all by 2030. It advocates for conservation and mains to enhance global resource base, by gradually changing the ways in which we develop and use technologies. Architecture is a field of study for planning and ordering of the built environment. Therefore, architects need to key into this plan to achieve the set goals as professionals by creating and preserving the quality of the built environment under the conditions of each community. This paper examines the role of Architects towards achieving the 17 goals of 2030 Agenda for Sustainable development in Nigeria. The research methodology adopted in this study is by review of related existing literature of the 17 sustainable development goals and finally developing a framework that can be adopted by architects in Nigeria to achieve a sustainable built environment. From the result of study, the impact of the goals were grouped into three parts; Major Challenge, Significant Challenge and Challenge remains. It concludes that architect's role in attaining this development goals is indispensable as their designs affects man, his activities and the built environment.
\end{abstract}

Keywords: 2030 Agenda, Sustainable Development, Architects, Built Environment, Nigeria

\section{Introduction}

Architecture is known to establish profound realities not easily altered once in place, therefore Architects as the master builder and more so, as a design community holds a responsibility towards buildings, humans and nature. [1] More than 700 million people of the world population with majority of them in sub-Saharan Africa survive on less than $\$ 1.90$ a day and struggle to fulfil the most basic needs of decent accommodation, health, access to portable water, Infrastructure etc. [2] The United Nations 2019 report on Sustainable Development Goals, provided a blueprint for shared prosperity in a sustainable world where all people can live productive, vibrant and peaceful lives on a healthy planet [2]. However, the sustainable development goals (SDGs) derived from the Millennium Development Goals (MDGs), defines the challenges we need to address today in other to achieve a better and more sustainable future for all.
In September 2015, the world leaders agreed on the Agenda 2030, which is framed into 17 Goals, and 230 Indicators. The main importance of the 2030 Agenda for Sustainable Development is "Inclusion" where they pledge to "leave no one behind" but also "to reach the furthest behind first" [3]. The Agenda does not only contain goals and targets, it also tackles the challenge of implementation and a framework for follow up and review [4]. These SDGs are universal, integrated and bring about transformation [5]. This means that the 17 SDGs apply to every nation; private and public sector and every profession especially architecture. The goals also emphasize on a systemic approach for a true synergy of the environmental, social and economic aspects of sustainability for solutions that will benefit people and the built environment. As human there is need to have a rethink in the way we live, and as professional it is apt to ask; how can we recreate a world to achieve all the 17 sustainable goals by the year 2030? Are our activities today as architects laying the right foundation to achieve the Sustainable 
Development Goals (SDGs)? Is there that needed collaboration between the private and public sector in Architecture in finding solutions that will benefit the people and prosper the nation? The results from the study concludes that the Architect has a vital role to play in achieving these sustainable development goal by 2030 and therefore, highlights their professional roles.

\section{The Sustainable Development Goals}

The most common definition of sustainable development is that of Brundtland Commission [6, 7]. which states that Sustainable development is the development that meets the needs of the present without compromising the ability of future generations to meet their own needs. The importance of this form of development is a stable relationship between human activities and the natural world, which does not diminish the prospects for future generations to enjoy a quality of life at least as good as our own [8]. This concept of conserving resources for future generations distinguishes sustainable development policy from traditional environmental policy, which also seeks to internalize the externalities of environmental degradation. [5]

Historically, the idea of sustainable development started with The United Nations Conference on the Human Environment held in Stockholm, Sweden in June 1972. It was the UN's first major conference on international environmental issues and marked a turning point in the development of international environmental politics [2]. The resolution by the general assembly in December 1983 was to establish the World Commission on Environment and Development which made a report on the environment its global problems with proposed strategies for sustainable development till the year 2000 [2]. In 1992 during the UN conference in Rio, Agenda 21 was formed which aimed at achieving global sustainability followed by the Earth Summit 2012 also held in Rio termed "The Future We Want" [6] which agreed on the reconciliation of the economic and environmental goals of the global community. 'Agenda 21' and 'The Future We' gave rise to the Millennium Development Goals [7] which was replaced by Sustainable development goals in 2015. The SDGs are focused on a global development for sustainability, and demonstrates an understanding that the environment is not in opposition to sustainable development, but the basis that support all other goals [9]. This means that while the MDGs focused on poverty reduction, the SDGs added an idea that sees the environment, economy and society as an integrated system rather than being separated. The Sustainable Development Goals (SDGs) builds on the success of the Millennium Development Goals (MDGs) but they go much further and tackle issues that affect people, the planet, prosperity, peace and partnership [10].

Another idea initiated to achieve sustainable development goals was the Oslo manifesto which has a slogan "the creative decision you make today have the power to shape the sustainable future of tomorrow" [11]. The purpose of the Oslo Manifesto is about energizing a movement of designers, architects and creative professionals to embrace the Sustainable Development Goals as design standards for a new sustainable world. It all started in Oslo on November 17, 2015, at the Framtanker conference where the discussion was about the critical role that design, architecture, and city planning play in the creation of a sustainable world. Members translated the SDGs into something that designers can work with. It is intended to serve far beyond the deadline of the UN Sustainable Development Goals 2030.

In Nigeria, construction is perceived as an economic process, rather than an ecological, socio-cultural way of responding to people's needs. This is a problem in the adoption of the sustainable development goal for the architect and other professionals of the built environment as most of them are yet to embrace the current practices that are friendly to the built environment [12]. There is also the increase in waste generation, inadequate supply of portable water, poor land use, inadequate facilities, and a general decline in human quality of life [12]. Another issue is the increase in unplanned cities which gave rise to slums, urban poverty, lack of infrastructure and basic amenities. There is also the issue of government funding the Sustainable Development Goals. It is quite clear that Nigeria is already facing fiscal challenges due to the declining oil revenues and lack of viable economy. For the MDGs, the government spent about 3 trillion annually as against the total of 4.3 trillion required to achieve the MDGs targets before the 2015 deadline. Consequently, it is assumed that funding the SDGs will be difficult with the decline in the economy [13]. The combination of the above-mentioned problems further compounds the challenges faced by Sustainable Development Goals in Nigeria's built environment.

\section{Methodology}

This research employed the qualitative research methodology to examine the role of architect in achieving the Sustainable development goals using basically secondary data. It is a literature review study with the main sources of data from journals, workshop papers, United Nation database and available statistics. It looks at the position of Nigeria in achieving the 17 sustainable development goals (SDGS). Data were analyzed by inferential deduction based on the author's opinion on the 17 SDGS and a framework developed. Each goal was identified, and the role architects can play in reaching them discussed. The impact of the goals was grouped into 3 parts; Major Challenge, Significant Challenge and Challenge remains.

\section{Results and Discussion}

West Africa is Africa's largest region with 15 countries and is home to the most populous black nation and largest economy on the African continent. Nigeria has the 9th largest 
urban population in the world and is home to some of the largest slums in the region [14]. Towards achieving the 17 SDGS, below is the average performance index of Nigeria

Nigeria ranks 43 out of 52 countries with a score of $47.03 \%$ which is poor [12]. From figure 1, it can be deduced that much attention has been paid to SD G13 (climate action) followed by SDG 12 (responsible consumption and production), and SDG 15 (life on land). The performance of SDG 7 (affordable and clean energy) is rising slightly above SDG 6 (clean water and sanitation), SDG 8 (decent work and economic growth), SDG 17 (partnership for the goals) and SDG 16 (peace, justice and strong institution). SDG 9 (infrastructure), SDG 10 (reduced inequalities) and SDG 11 (responsible consumption and production) face great difficulties while SDG 1 (poverty), SDG 2 (zero hunger) SGD 3 (good health and wellbeing), SDG 4 (education), and SDG 5 (gender equality) are slightly improving. However, the general performance is not encouraging and needs to be looked into. The roles architects have to play is summarized in table 1 below.

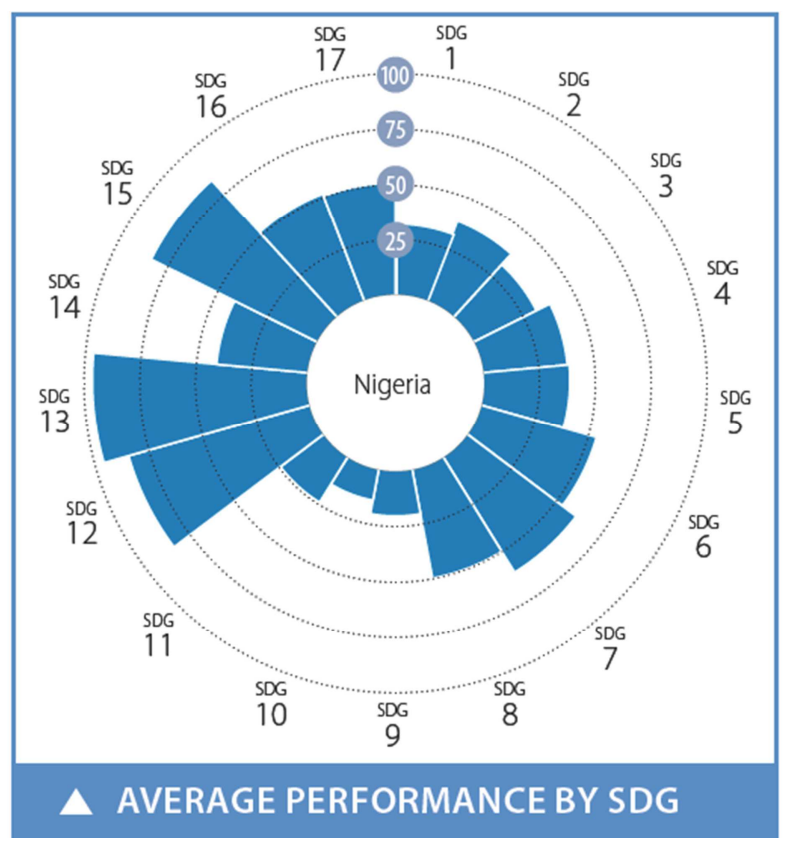

Source: UN report 2019

Figure 1. Nigeria SDG Index and Dashboards Report 2019.

Table 1. SDGS and architect's contribution in achieving the goals.

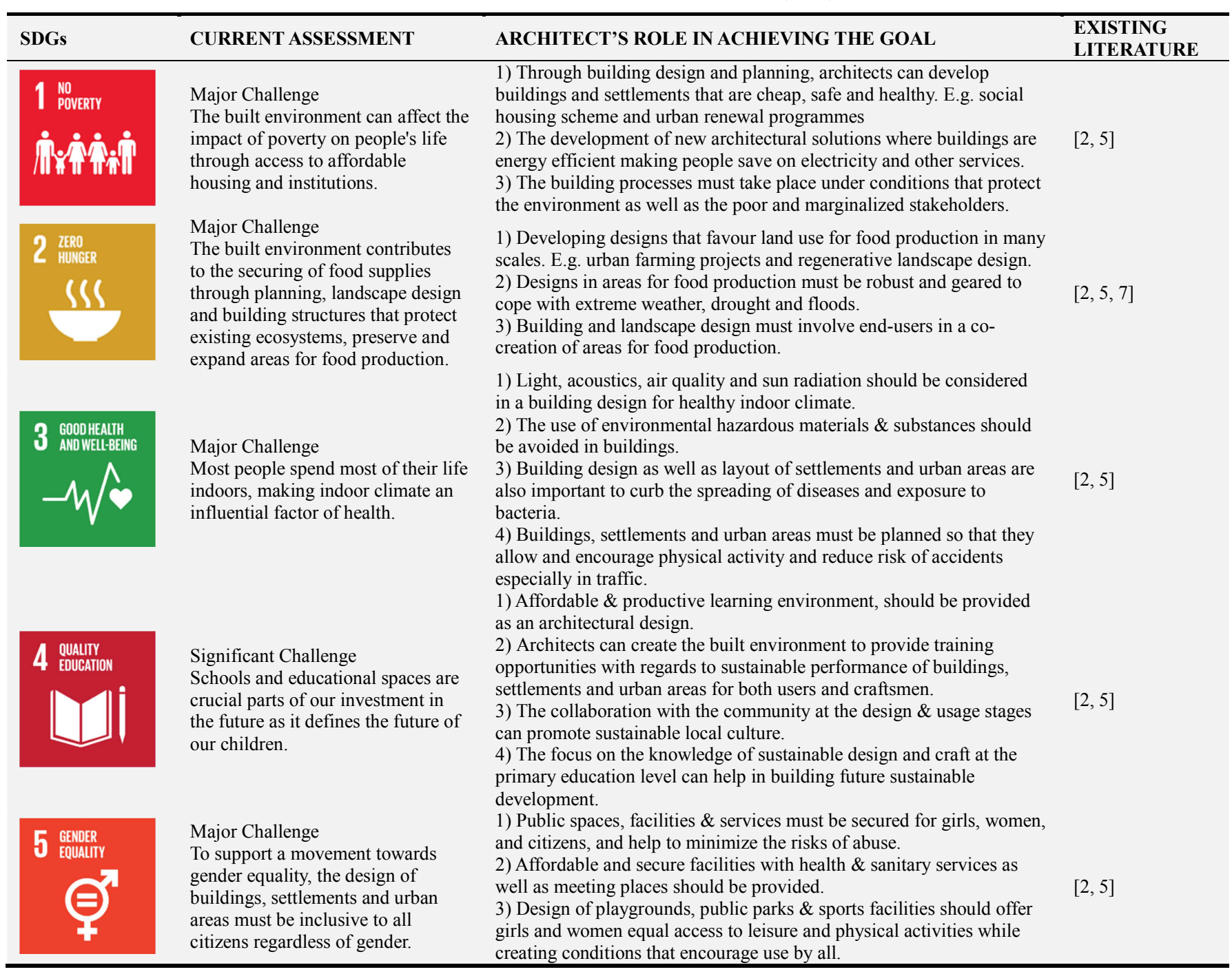




\begin{tabular}{|c|c|}
\hline SDGs & CURRENT ASSESSMENT \\
\hline $\begin{array}{l}\text { 6. CLEANWATER } \\
\text { ANDSANITATION }\end{array}$ & $\begin{array}{l}\text { Major Challenge } \\
\text { Access to water, sanitation and } \\
\text { hygiene is a human right, yet } \\
\text { billions are still faced with daily } \\
\text { challenges of accessing the most } \\
\text { amenities. Millions of people } \\
\text { including children die every year } \\
\text { from diseases associated with } \\
\text { inadequate water supply, sanitation } \\
\text { and hygiene. } \\
\text { Gender equality }\end{array}$ \\
\hline $\begin{array}{l}7 \text { AFFORDABLEAND } \\
\text { GLEANENEREY }\end{array}$ & $\begin{array}{l}\text { Major Challenge } \\
\text { Our everyday lives depend on } \\
\text { reliable and affordable energy } \\
\text { services to function smoothly and to } \\
\text { develop equitably. Energy is central } \\
\text { to nearly every major challenge the } \\
\text { world faces today. The need for } \\
\text { more access to clean fuel and } \\
\text { technology should be met regarding } \\
\text { integrating renewable energy to } \\
\text { end-use applications in buildings, } \\
\text { transport and industry. }\end{array}$ \\
\hline
\end{tabular}

8 DECENT WORKand 8 ECONOMIC GROWT 更

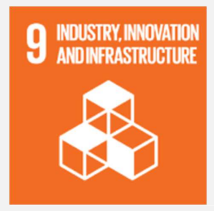

promoting inclusive and sustainable economic growth, employment and decent work for all as poverty eradication

is only possible through stable and well-paid jobs.

\section{Major Challenge}

There is need to build resilient infrastructure, promote sustainable industrialization and foster innovation.

\section{Significant Challenge}

Inequalities based on income, sex, age, disability, race, class, sexual orientation, ethnicity and religion continue to occur across the world; within and among countries. This threatens social and economic development as well as destroys people's sense of fulfilment and self-worth. It also causes crime, disease and environmental degradation

\section{Major Challenge}

The built environment is important to the development of sustainable cities and communities. With the increase in the number of people living within cities, it is important that efficient urban planning and management practices are in place to deal with the challenges that come with urbanization.
ARCHITECT'S ROLE IN ACHIEVING THE GOAL

EXISTING

4) The building industry must work towards equal pay, promote

diversity and oppose sexual harassment.

5) Architects from design to construction stages must avoid a narrowly gendered work culture, to promote diversity and ownership so that more women can join the profession.

1) Buildings and urban areas must be designed so that rainwater can be collected, purified and used as drinking water.

2) Rainwater should not be mixed with wastewater in order to it let enter the groundwater.

3) Buildings \& sewage systems should be designed to keep bacteria \& contaminated water separate from clean water and out of contact with citizens.

4) Building materials that do not contribute to groundwater contamination should be used during extraction and construction. 5) The built environment must be designed to withstand the climate change related to water, including extreme precipitation, drought and floods.

6) Landscape architecture and urban planning must protect freshwater resources through conservation projects and the design of recreational areas that protect, collect and handle water.

1) Reduction of energy consumption through optimal building layout and the built environment selection to minimize the excessive heating. 2) To produce and recycle energy, by storing excess heat during the day and employing it at night.

3) To analyze the given geographical, climatic and cultural conditions, and to design the built environment accordingly.

4) the use of daylight, natural ventilation or a choice of materials that support heating or cooling, such as heavy exterior walls in a hot and dry climate.

5) Building industry also should contribute to the reduction of total energy consumption through the development of solutions that employ innovative sources of renewable energy.

1) Safe public spaces \& affordable transit routes to the workplace are crucial for finding employment. The workplace should be designed as a healthy \& productive space for employees.

2) The building industry should focus on the decent working conditions and safety of workers.

3) The building industry can develop a more sustainable economic growth by investing in human resources, using improved skills and knowledge to reduce the amount of raw materials and energy needed while increasing productivity.

1) The Architect needs to develop innovative processes of production and assembly of industrial infrastructure.

2) The building industry should utilize the local industries by developing sustainable products locally. The focus must be from a no waste in production to a focus on lifecycle perspective.

3) Continuous research and development trainings are also required at all levels in the building industry, using prototypes to test the potential of new tools, processes and solutions.

1) Buildings, settlements and urban areas must be designed with accessibility as a core functionality. Lifts, ramps and wayfinding features should be given attention ion to doorways and the height of utilities.

2) Building, settlements and towns should be all elaborated on the central theme of accessibility and usability.

3) Inclusive design should aim at being used by all E.g. places of worship, public facilities of universal design.

1) Architects contribute in Many ways through design \& planning to make cities and settlements inclusive, safe, resilient and environmentally sustainable.

2) The provision of affordable and healthy living environment as well as infrastructure helps to reduce pollution from transportation, and, enhance mobility and accessibility between parts of a city, as well as between cities, rural areas.

3) Participation of all the stakeholders in the design process makes it possible to create inclusive and less risky urban design.

4) Building and settlements must be developed to increase resilience in 


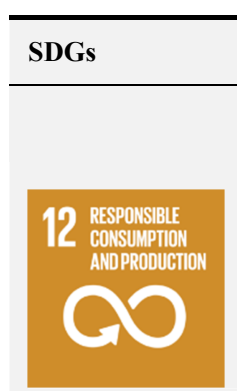

CURRENT ASSESSMENT

\section{Challenges Remain}

The building industry is a major contributor to waste from

construction, demolition or renovations. This causes pollution which become harmful to the built environment.

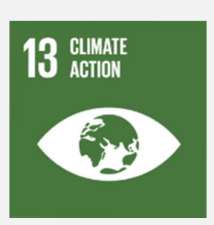

Challenges Remain

Climate change is an issue affecting every country. As it disrupts nationa economies and affects lives. Without action, the world's average surface temperature is likely to surpass $3^{\circ} \mathrm{C}$ this century with the poorest and most vulnerable people to be the most affected.

\section{Major Challenge}

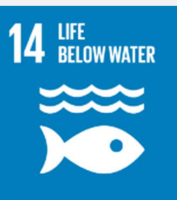

There is a continuous deterioration of coastal waters owing to pollution and ocean acidification is having an adversarial effect on the functioning of ecosystems and biodiversity. This is also negatively impacting smallscale fisheries.

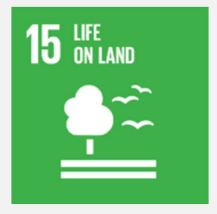

Challenges Remain Ecosystems and biodiversity are under intense pressure due to growing cities and settlements, farming, mining and the changing climate.

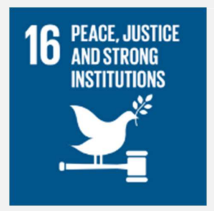

\section{Major Challenge}

People need to be safe from all forms of violence and feel free to go about their business whatever their ethnicity, faith or sexual orientation.

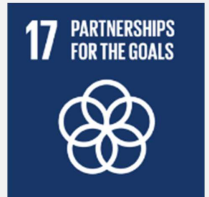

Major Challenge

The challenge of achieving the goals requires the involvement of all governments, Institutions, researchers, businesses and citizens.
ARCHITECT'S ROLE IN ACHIEVING THE GOAL

EXISTING

the face of climate change and include green areas to help counteract the loss of vegetation and biodiversity caused by urban growth.

1) Design considerations for durability and life cycles can reduce the components, buildings and structures.

2) Building materials can be recycled through its design and application.

3) New building materials and methods should be discovered to reduce the use of non-renewable natural resources while emphasizing on local materials.

1) To reduce the impact of $\mathrm{CO}_{2}$ in the built environment by integrating renewable energy production, expanding sustainable transportation systems, reducing transportation of building materials and emphasizing the use of local and renewable building materials.

2) By applying region specific building design, energy consumption for air-conditioning $\&$ lighting can be minimized, while maximizing the comfort of indoor environment.

3) The existing built environment must be adapted to the climate changing conditions like extreme rainfall, floods, hurricanes, drought and heat waves by applying new design solutions that are resilient to the changing conditions. This should be based on considerations of the local culture, topography and climate.

4) Architects should be responsible for developing climate adaptive which doubles as a recreational area between rainfalls.

1) Architects must reduce the amount of transportation of building materials over long distances by sea through the development of local industries, and the abolishment of plastic wrapping of building materials to reduce the source of non-biodegradable waste that ends up in the ocean.

2) Landscape Architects must ensure that pollutants like pesticides, nitrogen and human waste are handled on site and do not reach the groundwater or the oceans.

3) Architects can develop solutions that reduce cost and add benefits to water-managing infrastructure.

1) To protect, restore, and support ecosystems \& biodiversity, buildings and settlements must include habitats for plants, insects and animals.

2) To minimize greenfield developments and the development of all new settlements to ensure sustainable conditions for local eco-system, and the natural networks that allow plant life to attain the symbiotic relations with the built environment.

3) Building industry can avoid deforestation by using materials that are renewable and sustainably produced and which do not compromise biodiversity and natural habitats for flora and fauna.

4) Buildings placed carefully in vulnerable ecosystems or in wildlife parks can add to their preservation through sustainable tourism and increased public awareness.

1) Effective and inclusive public institutions are needed to give quality education and healthcare, fair economic policies and inclusive environmental protection.

2) Architects should support society's expression of its values through buildings and public spaces which should be inclusive, welcoming, secure, and non-discriminatory.

3) The building industry itself must pay close attention to procurement and construction processes in order to discourage all forms of organized crime, as well as ensure not to rely on abuse, exploitation, human trafficking or child labour.

1) Architects, can contribute by sharing knowledge, promoting sustainable solutions and engage in collaboration with research and institutional partners for the implementation. value loss and waste production in the building industry of individual solutions with co-benefits, such as overflow basins for extreme rainfall

\section{LITERATURE}

Source: UN report on SDG 2019.

SDG 1 can be achieved by the provision of affordable housing and institution to help alleviate poverty. There is a need therefore to achieve economic and social development in ways that do not exhaust a country's natural resources [8].
SDGs 2, 3, 4, 6 and 7 need reliable and conducive built structures to achieve it. SDG 8 needs the activities of the built sector to improve the economy while SDG 9 and SDG11, is about resilient infrastructure and resilient human 
settlements. This means that contemporary buildings have to become adaptable and function such that they meet the needs of their human occupants while at the same time preserving their external environment [15]. Inequality among countries addressed in SDG 10 requires buildings, settlements and urban areas to be designed with accessibility and usability as the main function. Then, SDGs 12, 1314 and 15 talks about how future development and sustainability will affect how our future structures are to be built. Design considerations for durability and life cycles can reduce the value loss and waste production in the building industry of individual components, buildings and structures. Also, the design and construction of resilient infrastructure that can withstand the challenges of climate change can be achieved by integrating renewable energy production, expanding sustainable transportation systems, reducing transportation of building materials and emphasizing the use of local and renewable building materials. This reduce the impact of $\mathrm{CO}_{2}$ in the built environment. By applying region specific building design, energy consumption for air-conditioning \& lighting can be minimized, while maximizing the comfort of indoor environment. Furthermore, Landscape Architects must ensure that pollutants like pesticides, nitrogen and human waste are handled on site and do not reach the groundwater or the oceans.

Lastly, goal 16 and 17 talks about peace, justice and partnership in achieving these goals. This explains how the built environment will achieve sustainability when these goals are met. Architects can contribute to achieving this goal by sharing knowledge, promoting sustainable solutions and collaborating with research and institutional partners for the implementation.

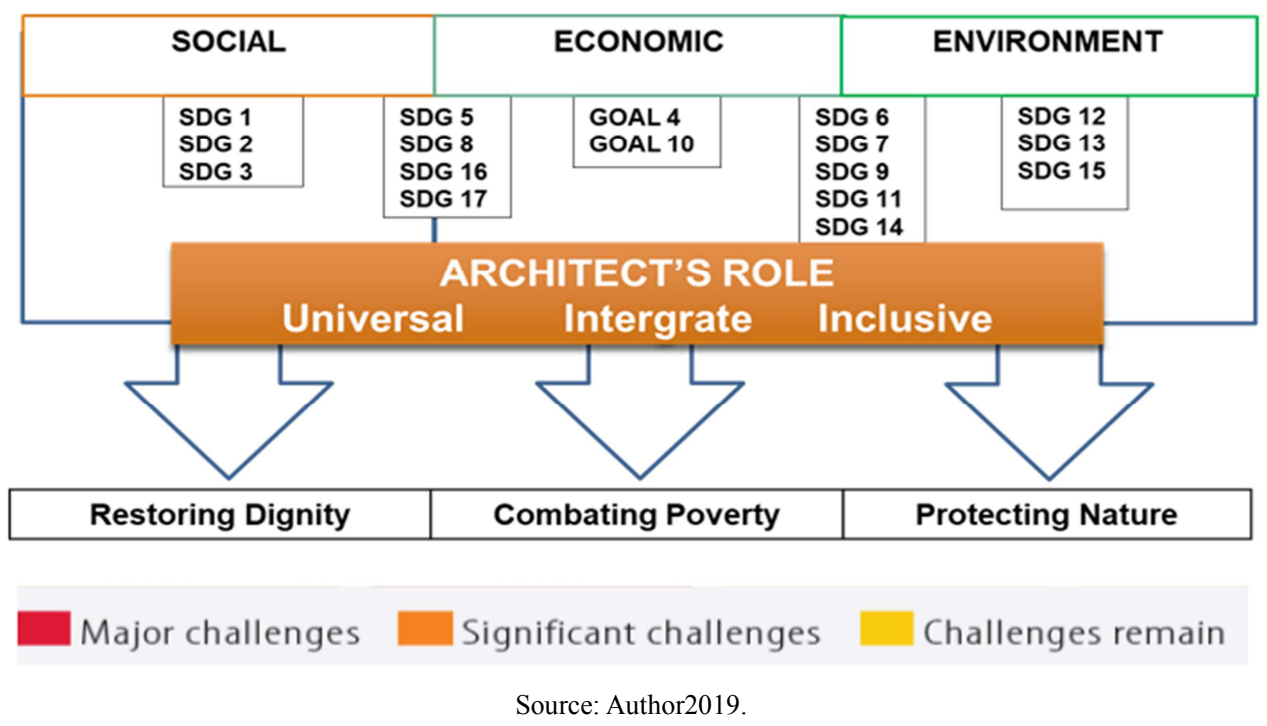

Figure 2. Framework for achieving the 17 SDGs by Architects.

\section{Conclusion and Recommendation}

Nigeria is stagnating in its progress on most goals towards reaching sustainability. However, SDG 13 (climate action) is on track to meet the goal. The challenge for Nigeria will be to overcome stagnancy in terms of health and social sustainability without affecting environmental sustainability. The findings from this paper show that architects have a critical role to play in a achieving these Sustainable Development Goals by preserving the built environment which gives prosperity to the people. The architect can highly influence the realization of SDGs directly or indirectly as the framework has spelt out their social, economic and environmental responsibilities which are linked to each other. As the leader in the construction industry they are key partner in the global effort to achieve sustainable development by 2030 through the development of sustainable infrastructural projects as the built environment can act as a driving force with the right government policies and strategies.

\section{References}

[1] Okeke, F. O., Chendo, I. G. and Sam-amobi, C. G. (2019) Resilient architecture; a design approach to counter terrorism in building for safety of occupants, 1st International Conference on Sustainable Infrastructural Development IOP Conf. Series: Mater. Sci and Eng. vol. 640 (2019) 012003. doi: 10.1088/1757-899X/640/1/012003.

[2] The Sustainable Development Goals Report 2019. United Nations document retrieved from https://unstats.un.org/sdgs/ report/2019/The-Sustainable-Development-Goals-Report2019.pdf.

[3] The European Disability Forum (2020) Why are the Sustainable Development Goals important. http://www.edffeph.org/why-are-sustainable-development-goals-important.

[4] Boto-Álvarez, A and García-Fernández, R. (2020) Implementation of the 2030 Agenda Sustainable Development Goals in Spain. Sustainability 2020, 12, 2546; doi: $10.3390 /$ su12062546. 
[5] United Nations (2018) An Architecture Guide to The UN 17 Sustainable Development Goals retrieved from https://www.nagel.ie/single-post/2018/12/20/An-ArchitectureGuide-to-the-UN-17-Sustainable-Development-Goals.

[6] Sustainable development 2019 international institute for sustainable development retrieved from www.iisd.org/.

[7] Danja I et al (2017) Hindrances to Sustainable Development Goals in Nigeria's Built Environment: A Review of Architects' Perception retrieved from

https://www.academia.edu/36291902.

[8] Nnaemeka-Okeke R. C (2016) Urban Sprawl and Sustainable City Development in Nigeria. Journal of Ecological Engineering Vol 17, Issue 2, Apr. 2016, pp 1-11. doi: $10.12911 / 22998993 / 62277$.

[9] Woodbridge, M and Zimmermann, M. (2015) From MDGs to SDGs: What are the Sustainable Development Goals? ICLEI BRIEFING SHEET - Urban Issues, No. 01 retrieved from www.iclei.org/briefingsheets.

[10] United Nations (2015) Transforming our world by 2030: A new agenda for global action Zero. Draft of the outcome document for the UN Summit to adopt the Post-2015 Development Agenda. New York: United Nations.
[11] Oslo manifesto 2016 Design and architecture for the SDGs retrieved from http://17goals.org /oslo-manifesto/.

[12] Ede, A et al (2016) Impact of Reliable Built Structures in Driving the Sustainable Development Goals: A look at Nigerian Building Structures. (CU-ICADI) International Conference on African Development Issues May 9-11 2016, Ota, Nigeria.

[13] Opoku A (2016) SDG2030: A Sustainable Built Environment's Role in achieving the Post-2015 United Nations Sustainable Development Goals. Proceedings of the 32nd Annual ARCOM Conference, 5-7 September 2016, Association of Researchers in Construction Management, Manchester, UK Volume: Vol 2, 1149-1158.

[14] UNDP International Consultant to Study of Impacts of Climate Change and Disasters on Health in Urban Areas, Ethiopia. (2010) Retrieved online at https://uncareer.net /vacancy/international-consultant-study-impacts-climatechange-and-di accessed 9th October 2019.

[15] Okeke, F. O., Okekeogbu, C. J and Adibe, F. A. (2017) Biomimicry and sustainable architecture: A review of existing literature Journal of Environmental Management \& Safety Vol. 8, No. 1, pp 11-24. 